\title{
メッシュデータに立脚した同種・異種土地利用の集塊性の把握手法 \\ A METHOD TO ANALYZE CHARACTERISTICS OF AGGLOMERATION OF THE SAME AND DIFFERENT KINDS OF LAND USE USING GRID DATA
}

\author{
吉川徹* \\ Tohru YOSHIKAWA
}

\begin{abstract}
The objective of this article is to develop a method to analyze characteristics of agglomeration of land use based on grid data. To this end, a method which uses the average ratios of edges of each grid with the same and different kinds of land use (called as Edge Ratios : ERs ) is formulated based on JOIN-COUNT statistics and Same Edge Ratio (SER) . Among ERs, the average ratios of edges with the different kinds of land use are especially called as Different Edge Ratios : DERs. The expected value and the variance of DER are calculated and a statistical test is formulated.
\end{abstract}

Keywords: land use, agglomeration, grid data, JOIN-COUNT statistics, edge ratio 土地利用, 集塊性, メッシュデータ, join分析, 辺率

1 はじめに

この論文の目的は土地利用の集塊性の分析手法の開発である.こ のためメッシュ土地利用データを使った，各メッシュの周囲の 4 辺 (join) が種々の土地利用と接する辺の比率（辺率と呼ぶ）に基づく分 析手法を提案する.なお，この論文の内容は著者による既口頭発表 ${ }^{1)}$ に新たな研究成果を加えたものである.

土地利用のパターンの特徴のなかで都市計画で重要なものとして, 同種や異種の土地利用の集塊性が挙げられる.このため，後述のよ うにこれを分析する様々な手法が提案されてきた．この集塊性には 様々な切り口が考えられる．たとえば一戸の低層住宅にとっては，土 地利用に関する基本的な関心事は隣接する敷地の土地利用であろう。 このように，一戸の低層住宅などの一単位の土地から見たときの隣 接する土地利用の状態を調べることは有意義であろう．そこでここ では，一単位の土地の周囲に同種や異種の土地利用がどのように隣 接しているかという観点から土地利用の集塊性を分析する．この観 点から見た集塊性を隣接集塊性と呼ぼう4).

同種の土地利用の隣接集塊性は吉川2)3)4)が扱っているので，これ を発展させて異種土地利用を含めた隣接集塊性を分析する手法を開 発しよう. なお, 土地利用区分が 2 䅉類しかない場合には, 同種と異 種の土地利用の隣接集塊性は同じ現象の表裏を見ていることになる。
そこでここでは土地利用区分ぶ 3 種類以上ある場合を扱う。

2 join 分析

土地利用の集塊性を分析する既存の手法としては, join 分析 5)6)7)8)9) 10)11)12), エントロピー6)8)9)13)14), clump 分析6)8)10)，士 地利用の隣接行列の固有ベクトル15)，土地利用の敷地間接触線数 ${ }^{10)}$, 土地利用の隣接長 ${ }^{10) 16)}$, 土地利用の塊の形状俰数 ${ }^{16)}$ や形態指数 ${ }^{17)}{ }^{18)}$, 同種の土地利用への隣接集塊性を測る同边率2)3）4）などが挙げられ る.これらの中には特に異種上地利用を含めた隣接集塊性に着目し たものは見当たらない，

しかし join 分析はメッシュを土地利用の単位とした土地利用の隣 接状態の分析手法であり，これに立脚して隣接集塊性の分析手法を 構成できると期待される．この手法はメッシュ土地利用データにお いて，対象地城の内部（境界は含まない）のメッシュの辺のうち，土 地利用 $\alpha$ とが接している辺（ $\alpha-\beta$ join と呼ぶ）の数を指標とするもの である. 特に土地利用が 3 種類以上ある場合は, color join 分析と呼 ばれる手法が提案されている.

たとえば図 1 では，太線の内側を対象地域とすれば，低層住宅-中 高層住宅 join は 3 本となる.こり数が多いほど, 土地利用 $\alpha$ と $\beta$ は隣 接する傾向が滈いと判断される。

\footnotetext{
* 東京都立大学工学研究科建築学尃攻 助教授・博士 (工学) 


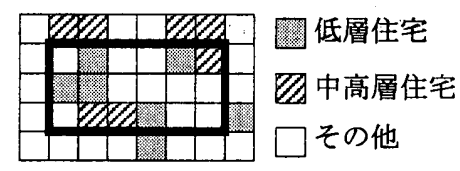

図 1:メッシュ土地利用図の例

このときに問題になるのが join の数の大小の判断基準である. 代 表的なものは次のふたつである.

ランク值 ランダムな土地利用図での join の確率分布を根拠として, 次式で計算する5)6)7)8)12).

$$
\text { ランク值 }=\frac{\text { join 数 }- \text { join 数の期待值 }}{\text { join 数の標準偏差 }}
$$

これは, 統計処理で多用される $\mathrm{z}$ 変換と呼ばれる基準化手法である. join 数ではこの值はメッシュ総数が増加すれば漸近的に標準正規分 布に従うことが既に証明されているたとえば8)。

絶対値 武内ら ${ }^{11)}$ は混在程度の絶対的な大きさを評価する場合には join 数そのものが基淮として妥当だとした。

以上を踏まえjoin 分析を修正した手法を開発しょう。

\section{3 辺率}

たとえば一戸の低層住宅を考えたとき，隣接集塊性の指標として もっとも簡明なものは, 敷地の周囲のうち, 道路, 中高層住宅など の土地利用と接している部分の占める比率であろう。これはメッシュ を単位とすれば, 周囲の 4 辺のうち特定の土地利用のメッシュと接 している辺（join）の比率を指標とすることに相当する.

たとえば図 1 のメッシュ土地利用図の黒枠の内側を対象地域としよ う. 低層住宅のメッシュ（5 個）に着目すると, 中高層住宅に接して いる辺の数はそれぞれ $0,1 ， 1 ， 1 ， 2$ となり，4で割って比率に值す と $0,0.25,0.25,0.25,0.5$ となる. その平均値 0.25 は, 対象地域 の低層住宅のメッシュを一個任意に取り出したときに, その周囲 4 辺 のうち中高層住宅に接している辺の比率の期待值となる.そこでこ の値を低層住宅メッシュから見た中高層住宅メッシュの辺率（低層住 宅-中高層住宅辺率と略そう）と呼んで，隣接集塊性の指標としょう. 図1で辺率を計算すると表1が得られる.

表 1: メッシュ土地利用図の例での辺率

\begin{tabular}{c||c|c|c|c|c} 
土地利用 & $\begin{array}{c}\text { メッ } \\
\text { シュ }\end{array}$ & 構成比 & \multicolumn{3}{|c|}{ 辺率 } \\
& & & 低層 & 高層 & その \\
数 & & & 住宅 & 住宅 & 他 \\
\hline 低層住宅 & 5 & .278 & .250 & .250 & .500 \\
高層住宅 & 3 & .167 & .250 & .250 & .500 \\
その他 & 10 & .556 & .250 & .100 & .650
\end{tabular}

この辺率のうち低層住宅-低層住宅辺率など同種の土地利用に対す る辺率は吉川2)3)4)による同種土地利用の隣接集塊性の指標である同 辺率に一致する.したがって辺率は同辺率を異種土地利用まで拡張 した指標である．以降では，辺率のうち低層住宅-中高層住宅辺率な ど異種の土地利用に対するものを特に区別する必要があるときには， これを異辺率と呼ぶことにする.

なお，1 から同辺率を引いた值は，土地利用の塊の周囲の join 数 をメッシュ数の 4 倍で割った值になる．したがって，同辺率は土地利
用の塊の面積を周長で除した形状係数 ${ }^{16)}$ や，画素単位で周長を面積 で除した形態指数17)18) と類似性を持っている.

しかし, 形状係数 ${ }^{16)}$ はメッシュなどの一単位の土地に着目したもの ではなく，また形態指数17)18) は, join ではなくメッシュあるいは画 素の数をもって境界線長とする点で, 辺率とは異なった指標である.

\section{1 辺率とメッシュサイス}

吉川(4)は同辺率に関してメッシュサイズを变化させたときの挙動は 末解決の課題であることを指摘した. 同様に異辺率もメッシュサイズ を変えると変化する. したがって, 辺率の解釈に当たってはメッシュ サイズを念頭に置く必要があり，原則として同じメッシュサイズから 算出された辺率を比較すべきである注 1)，

\section{2 東京都八王子市・多摩市における実例}

実例として表 2 に東京都八王子市明神町付近の $500 \mathrm{~m}$ 四方の地域の 1989 年の辺率を示した. 土地利用の資料は国土地理院細密数值情報 $10 \mathrm{~m}$ 土地利用データ19)を用いた. したがって，メッシュ数は $50 \times 50$ で 2500 個となる．またメッシュサイズは $10 \mathrm{~m} \times 10 \mathrm{~m}$ となり，面積 は $100 \mathrm{~m}^{2}$ と市街地での小規模な宅地の規模にほぼ該当している。

なお, 細密数值情報の土地利用区分のうち, 農地系と空地系を空 地, 一般低層住宅と密集低層住宅を低層住宅に, 公園緑地と公共公 益施設とその他を公共施設にそれぞれ併合した。

表 2: 東京都八王子市明神町付近の 1989 年の辺率

\begin{tabular}{c||c|c|c|c|c|c|c}
\multicolumn{1}{c|}{ 区 } \\
分
\end{tabular}

この表の, 特に低層住宅と高層住宅の隣接集塊性に着目しょう。低 層住宅の周囲のうち高層住宅はおよそ $3 \%$ を占める. 一方で高層住宅 の周囲のうち低層住宅の占める割合はおよそ $17 \%$ と高い.ここで比 較のため, 東京都多摩市愛宕について, 同様に $500 \mathrm{~m}$ 四方の対象地域 で低層住宅と高層住宅に関する辺率を計算した。

\section{表 3: 東京都多摩市愛宕付近の 1989 年の辺率（一部）}

\begin{tabular}{c||c|c|c|c|c|c|c}
\multicolumn{1}{c||}{ 区 } & \multicolumn{9}{c}{ 辺率 } \\
分 & 空地 & 工業 & 低層 & 高層 & 商業 & 道路 & 公共 \\
& & 用地 & 住宅 & 住宅 & 業務 & & 施設 \\
\hline 低 & .172 & .000 & .646 & .011 & .011 & .143 & .018 \\
高 & .072 & .000 & .017 & .851 & .001 & .055 & .005 \\
\hline 比 & .366 & .006 & .205 & .131 & .030 & .200 & .061
\end{tabular}

この結果から, 愛宕では低層住宅一高層住宅辺率はおよそ $1 \%$, 高 層住宅一低層住宅辺率はおよそ $2 \%$, 明神町に比べて低いことがわ かる. そこで両地域の, 低層住宅, 高層住宅の分布図を作成した（図 2).これを見ると，既成市街地に高層住宅が立地する明神町では，小 規模な高層住宅が散在している.これに対して，多摩ニュータウンを 
含む愛宕では，高層住宅が集中して立地している部分がある．この両 地域の成り立ちの違いが辺率の違いに反映していることがわかる.

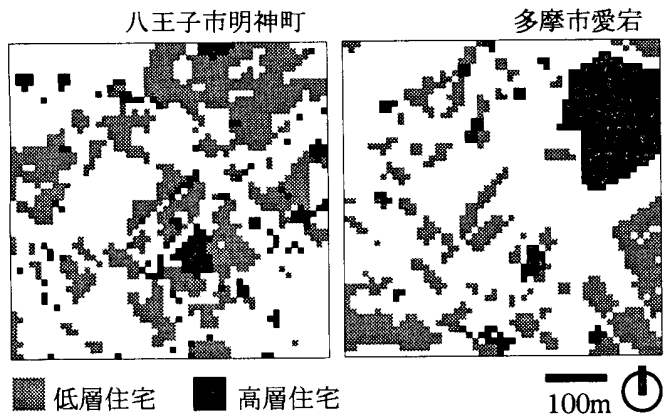

図 2: 明神町と愛宕の低層住宅, 高層住宅の分布

\section{3 辺率の定義}

以下の議論のために, ここで辺率を記号を使って定義しておこう. まず用語と記号を定義する.

内部メッシュ 対象地域に含まれるメッシュ

外接メッシュ 対象地域に隣接するメッシュ

内部 join 内部メッシュ同士が接する join. $y_{i}(\alpha, \beta), i=1 \ldots N(y)$ で表わす.ここで $\alpha$ とは土地利用を, $N(y)$ は内部 join の総数を表 わす. $y_{i}(\alpha, \beta)$ の值は, $y_{i} か ゙ ~ \alpha-\beta$ join $(\alpha \neq \beta)$ ならば $1, y_{i}$ が $\alpha$ - $\alpha$ join (つまり $\alpha=\beta$ ) ならば 2 , これ以外は 0 とする。

境界 join 内部メッシュと外接メッシュが接する join.つまり対象地 域の境界の join. $z_{j}(\alpha, \beta), j=1 \ldots N(z)$ で表わす. ここで $N(z)$ は境 界 join の総数とする. $z_{j}(\alpha, \beta)$ の值は, その境界 join の内部メッシュ の土地利用が $\alpha$ かつ外接メッシュの土地利用が $\beta$ であれば $1 （ \alpha=\beta$ の場合を含む)，それ以外では 0 とする.

さらに対象地域内の土地利用 $\alpha$ のッシュ数を $M_{\alpha}$ としよう.する と $\alpha-\beta$ 辺率 $x(\alpha, \beta)$ は次式で定義される.

$x(\alpha, \beta)=\frac{1}{4 M_{\alpha}}\left(\sum_{i=1}^{N(y)} y_{i}(\alpha, \beta)+\sum_{j=1}^{N(z)} z_{j}(\alpha, \beta)\right)$

\section{4 ランダムな地利用図での挙動に基づく辺率の解釈}

上記の例のように，辺率はそれ自体が周囲の覆われ方という意味 を持ち，絶対値による解釈や比較が可能である. しかし土地利用構 成比の大小を加味して解釈したい場合もある。この時には別の判断 基淮が必要である。

土地利用の分析では, 第 2 章で述べたように, このような場合に判 断基準としてランダムな土地利用図での指標值の挙動を参照するこ とがよくある．同辺率は，ランダムな土地利用図では漸近的に期待 值が土地利用構成比に収束することが判明している3)4). そこでここ では，異辺率のランダムな土地利用図での挙動を調べることで，土 地利用構成比の大小を加味した辺率の解釈方法を検討しょう.

ランダムな土地利用図のモデルとしては, 吉川2)3)4) と同様に各メッ シュが独立に一定の出現確率で特定の土地利用になるもの ${ }^{20)}$ を採用 しよう. なお，このモデルでは, 特定の土地利用のメッシュ数が 0 に なることがある. $\alpha-\beta$ 辺率は分母が土地利用 $\alpha$ なッシュ数となるの で,これが 0 になると定義できない，そこでここでは $\alpha-\beta$ 辺率の期待
値は土地利用 $\alpha$ のメッシュ数が 0 になる場合を除いて計算しよう.

異辺率の挙動を調べるには，原点回りの $k$ 次モーメントを定式化す ると便利である．そこでまずこの定式化を行っておこう。

始めに記号を定義する．対象地域の全メッシュ（内部メッシュ）の 総数を $t$ とする. $t=1$ のときは対象地域が 1 個のメッシュであるの で自明であるから， $t \geq 2$ とする. 内部メッシュの辺（総数 $4 t ）$ は, 境界 join と, 向かい合う 2 辺が構成する内部 join に分かれる. 従っ て境界 join 数 $N(z)$ は $4 t-2 N(y)$ となる. また土地利用 $\alpha, \beta$ の出現 確率をそれぞれ $p_{\alpha}, p_{\beta}$ としよう。

ここで土地利用 $\alpha$ のメッシュ数が $M_{\alpha}$ である確率を $P_{\alpha}\left(M_{\alpha}\right)$ として， これを $M_{\alpha}=0$ の場合を除外して計算すると, 次式が得られる.

$P_{\alpha}\left(M_{\alpha}\right)=\left(\begin{array}{c}t \\ M_{\alpha}\end{array}\right) \frac{p_{\alpha}^{M_{\alpha}}\left(1-p_{\alpha}\right)^{t-M_{\alpha}}}{1-\left(1-p_{\alpha}\right)^{t}}$

これを用いると, 辺率 $x$ の原点回りの $k$ 次モーメント $\mathrm{E}\left[\boldsymbol{x}^{k}\right]$ は次式 になる．なおこの式では，土地利用 $\alpha$ なッシュ数が $M_{\alpha}$ であるとい う条件のもとでの, 確率変数 $w$ の期待値を $\mathrm{E}\left[w \mid M_{\alpha}\right]$ で示してある.

$$
\begin{aligned}
\mathrm{E}\left[x^{k}\right]= & \sum_{M_{\alpha}=1}^{t} P_{\alpha}\left(M_{\alpha}\right) \mathrm{E}\left[x^{k} \mid M_{\alpha}\right] \\
= & \sum_{M_{\alpha}=1}^{t} \frac{P_{\alpha}\left(M_{\alpha}\right)}{\left(4 M_{\alpha}\right)^{k}} \\
& \mathrm{E}\left[\left(\sum_{i=1}^{N(y)} y_{i}(\alpha, \beta)+\sum_{j=1}^{N(z)} z_{j}(\alpha, \beta)\right)^{k} \mid M_{\alpha}\right]
\end{aligned}
$$

\section{1 辺率の期待值}

上記のように同辺率は，ランダムな土地利用図では漸近的に期待 值が土地利用構成比に収束するので, 土地利用構成比と同辺率を比 較することで解釈が可能である4)，そこで，異辺率についても期待值 を算出しよう.

$\alpha-\beta$ 辺率は，対象地域の任意の土地利用 $\alpha$ のッシュを取り出した 時の, その周囲の 4 本の join のうちの土地利用 $\beta$ と接する join の比 率の平均值である。したがって，直観的には辺率の期待值は土地利 用 $\beta$ の出現確率 $p_{\beta}$ に等しいと予想される. しかし，実際に式 (3) で $k=1$ として期待值 $\mathrm{E}[x(\alpha, \beta)]$ を計算すると, 次の式が得られる.

$$
\mathrm{E}[x(\alpha, \beta)]=p_{\beta}+p_{\beta} \frac{N(y)}{2}\left(\frac{1-\frac{p_{\alpha}}{1-\left(1-p_{\alpha}\right)^{t}}}{(t-1)\left(1-p_{\alpha}\right)}-\frac{1}{t}\right)
$$

この式から上記の予想は成立しないことがわかる. そこで期待值

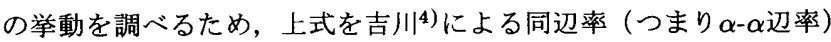
の期待值 $(\mathrm{E}[x(\alpha, \alpha)]$ と書こう) と比べると, 次式が得られる.

$\mathrm{E}[x(\alpha, \beta)]=\frac{p_{\beta}}{1-p_{\alpha}}(1-\mathrm{E}[x(\alpha, \alpha)])$

この式から, $\mathrm{E}[x(\alpha, \alpha)]=p_{\alpha}$ であれば上記の予想が正しいことが わかる. しかし実際には $\mathrm{E}[x(\alpha, \alpha)]<p_{\alpha}$ であることが判明している 4).ただし対象地域が $50 \times 50$ 程度のメッシュ地図より大きければ両 者はほぼ等しいことが判明している゙).

したがって $\mathrm{E}[x(\alpha, \beta)]$ は $p_{\beta}$ より大きいが，対象地域が $50 \times 50$ メッ シュより大きけれぼ $p_{\beta}$ で近似できる. 以上より, 対象地域の規模が $50 \times 50$ メッシュ程度より大きけれは，ランダムな土地利用図では $\alpha-\beta$ 辺率は, 同辺率つまり $\alpha=\beta$ の場合を含めて, 土地利用 $\beta$ の出現 確率（つまり構成比） $p_{\beta}$ にほぼ等しい. 


\section{2 期待値に基づく辺率の解䣋}

このことから, 実際の $\alpha-\beta$ 辺率が土地利用 $\beta$ の構成比より大きけれ ば，土地利用 $\alpha$ の周囲には土地利用 $\beta$ 集まる傾向があると判断でき る. ただしこの傾向が有意であるかどうかは別途判断する必要があ る.このためには，異辺率の確率分布が判明していれば便利である しかし, この確率分布を正確に求めることは極めて困難であると予 想される.この理由として, 後述のように, 式(1)の $y_{i}, z_{j}$ は互いに 独立でないことや，辺率が離散的な值を取ることが挙げられる．

そこで，モンテカルロシミュレーションによって確率分布を近似的 に求めて，これをもとに統計的検定を行った．シミュレーションにあ たっては，ランダムな土地利用図を $1,000,000$ 回発生させた．結果と して，八王子市明神町（表 2) においては，下線がない項目は $1 \%$ 有 意，一重下線の項目は $5 \%$ 有意となった。 また，多摩市愛宕（表 3） においては，すべての項目が $1 \%$ 有意であった.

ここで，表 2 ，表 3 を見ると，ほとんどの土地利用区分で，同辺率 は有意に土地利用構成比より大きく, 異辺率は有意に土地利用構成 比より小さいことがわかる．これは，対象地域では $10 \mathrm{~m} \times 10 \mathrm{~m}$ の メッシュを単位として見れば，同種の土地利用は集まる傾向があり， 異種の土地利用は互いに離れる傾向があることを意味している。こ の例外は, 八王子市明神町の高層住宅と道路の閒の関係であり, 両者 の間の異辺率はともに有意に土地利用構成比より大きい。このデー タが 10m メッシュであることを考慮すると，八王子市明神町におい ては, 高層住宅の周囲には広幅員の道路が多く, また広幅員道路の周 囲には高層住宅が多いことがわかる。

\section{5 辺率の $\mathrm{z}$ 変換}

以上より, 土地利用構成比を勘案した辺率の解釈が可能になった. これをより簡単に行う方法として，第 2 章で述べた join のランク値 を参考にして，辺率を $\mathrm{z}$ 変換することが考えられる。このためには， 辺率の分散を求める必要がある.このうち，同辺率の分散について は既に論じられている4)ので，ここでは異辺率の分散を調べよう。

\section{1 異辺率の分散の解析的な算出}

分散 ( $\sigma^{2}$ とする) は, 式 $(3)$ の辺率 $x$ の原点回りの k次モーメント $\mathrm{E}\left[\boldsymbol{x}^{k}\right]$ を用いれば, 次式で求められる.

$\sigma^{2}=E\left[x^{2}\right]-(E[x])^{2}$

ここで第 2 項は式 (4)の期待值の自乗であるので, 第 1 項，つまり原 点回りの 2 次モーメントを求めよう.

しかしこれを求めるのは，同辺率の場合4) と同様に，期待値ほど簡 単ではない. 式 $(3)$ を $k=2$ として展開すると, $y_{i} y_{j}, y_{i} z_{j}, z_{i} z_{j}$ と いった項の期待值が出現する. これらの項の期待値は，ペアになった join が図3に示すように互いにメッシュを共有する，つまり独立でな い場合と，それ以外では異なる．そこで，メッシュを共有する join の ペアを数え尽くす必要がある。

まず記号を定義しよう.

$N(y \cdot y)$ : 内部 join 同士のペアのうち内部メッシュを共有するペア の数（図3のAのふたつのパターン）

$N(y \cdot z)$ : 内部 join と境界 join のペアのうち内部メッシュを共有 するペアの数（図 3 のB $\mathrm{B}$ ふたつのパターン）

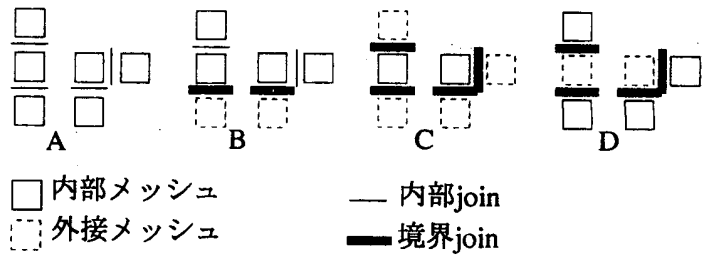

図 3: メッシュを共有する join のペア4)

$N i(z \cdot z) ：$ 境界 join 同士のペアのうち内部メッシュを共有するぺ アの数（図3のCのふたつのパターン）

$N o(z \cdot z)$ : 境界 join 同士のペアのうち外接メッシュを共有するぺ アの数（図 3 の D ふたつのパターン）

$\min (a, b): a$ と $b$ のちの小さい方の值

$$
\begin{aligned}
q_{\beta}= & p_{\beta} /\left(1-p_{\alpha}\right) \\
M(1)= & N(z) p_{\beta}+2 N(y) q_{\beta}+2 N i(z \cdot z) p_{\beta}^{2} \\
& +2 N(y \cdot z) p_{\beta} q_{\beta}+2 N(y \cdot y) q_{\beta}^{2} \\
M(2)= & 2 N o(z \cdot z) p_{\beta}+2(N(y \cdot y)-N(y)) q_{\beta} \\
& +(2 N(y) N(z)-N(y \cdot z) \\
& +N(z)(N(z)-1)-2(N i(z \cdot z) \\
& +N o(z \cdot z))) p_{\beta}^{2}-2 N(y \cdot z) p_{\beta} q_{\beta} \\
& +(N(y)(N(y)-1)-6 N(y \cdot y)) q_{\beta}^{2} \\
M(3)= & -2 N(y \cdot y) q_{\beta} \\
& -2(N(y)(N(y)-1)-N(y \cdot y)) q_{\beta}^{2} \\
M(4)= & (N(y)(N(y)-1)-2 N(y \cdot y))
\end{aligned}
$$

これらを使用することで, 式 (3) で $k=2$ とした結果を整理すれ ば, $\mathrm{E}\left[\boldsymbol{x}^{2}\right]$ が次式として得られる.

$\mathrm{E}\left[x^{2}\right]=\sum_{M_{\alpha}=1}^{t} \frac{P_{\alpha}\left(M_{\alpha}\right)}{16 M_{\alpha}^{2}}\left(\sum_{c=1}^{\min \left(M_{\alpha}, 4\right)} M(c) \frac{M_{\alpha} !(t-c) !}{\left(M_{\alpha}-c\right) ! t !}\right)$

なお, 縋 $m$ メッシュ, 横 $n$ メッシュからなる長方形の対象領域で は次式が成り立つ4)。

$$
\begin{aligned}
N(y \cdot y) & =6 m n-6(m+n)+4(\text { 玉川8) 参照 }) \\
N(y \cdot z) & =4 \\
N i(z \cdot z) & =6(m+n)-8, \quad N o(z \cdot z)=0
\end{aligned}
$$

これらを代入すれば原理的には式 (7)が求められる.しかし，この式 には式 (2)の $P_{\alpha}\left(M_{\alpha}\right)$ が含まれており，これが二項分布確率を含む. このため, 計算時にメッシュ総数 $t$ から任意の個数を選ぶ組み合わせ の数の算出が必要となる. $t$ が大きくなると組み合わせの数が膨れあ がるので単密な計算が困難になる，したがって，別の方法で分散を 推定する必要がある.

\section{2 モンテカルロシミュレーションによる分散の算出}

そこで，検定と同様に，モンテカルロシミュレーションによって分 散を求めよう．ランダムな土地利用図を $1,000,000$ 回発生させて八王 子市明神町（表 2）について分散を求めた結果は次表になる.ただし この表では分散の平方根をとって標淮偏差で表示した. 
表 4: 八王子市明神町の 1989 年の辺率の標準偏差

\begin{tabular}{l||c|c|c|c|c|c|}
\multicolumn{1}{l|}{ 区 } & \multirow{2}{*}{ 分 } \\
\end{tabular}

ここで式 $(7)$ を見ると， $\mathrm{E}\left[x^{2}\right]$ は， $p_{\alpha}$ については複雑な関数である

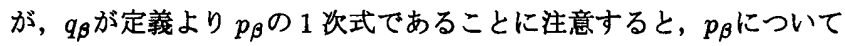
は 2 次式であることがわかる．また， $(\mathrm{E}[\boldsymbol{x}])^{2}$ は式 $(4)$ より $p_{\beta}$ の 2 次 式である. 以上より分散 $\sigma^{2}$ は $p_{\beta}$ の 2 次式になる．そこで，上記のモ ンテカルロシミュレーションの結果に共通の $p_{\alpha}$ ごとに $p_{\beta}$ の 2 次式を 当てはめたところ，次の結果が得られた．なお同辺率は分散の式が 異なる゙)ので当てはめから除外した.

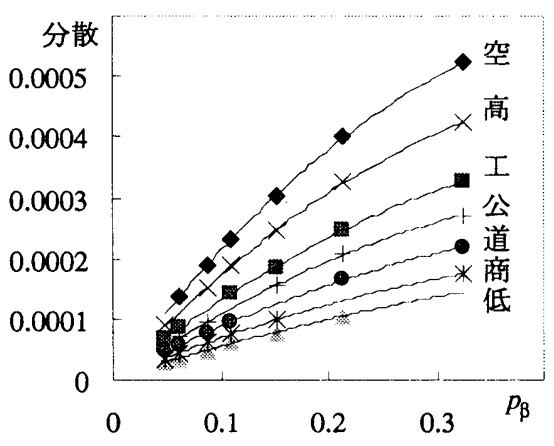

図 4: 分散への 2 次式のあてはめ

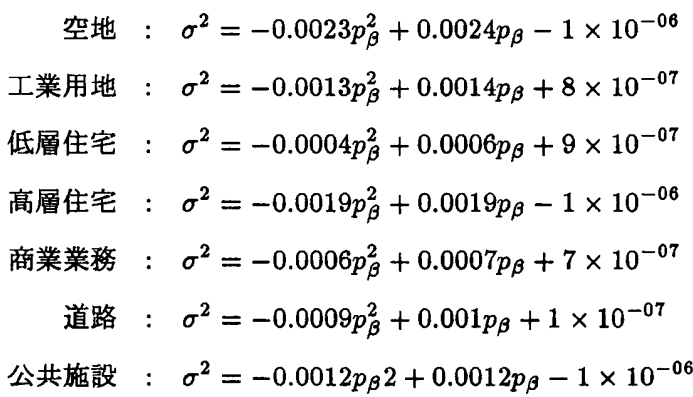

決定係数は，低層住宅が 0.9999 であり，ほかはすべて 1.0 である. この高い決定係数から，モンテカルロシミュレーションから求められ た分散の精度は高いと考えられる．また，定数項は分散の值に比べ て小さく，ほとんど0に等しい，これは，異辺率の定義から， $p_{\beta}=0$ のときは異辺率もかならず 0 となり，結果として分散も 0 となるこ とから納得できる.

\section{3 辺率の $\mathrm{z}$ 変換}

以上で求められた辺率の分散を使って，表 2 の辺率を $\mathrm{z}$ 変換した結 果，表 5が得られた。この表によれば，表 2で帰無仮説が棄却されな かったり，相対的に有意度が低い $5 \%$ 有意であったところでは， $\mathrm{z}$ 変
換值の絶対値が相対的に小さく，ほぼ 2 程度である.このことから， $\mathrm{z}$ 変換值が比較の目安として使用できることがわかる.

しかし, join の場合とちがって, 辺率では $\mathrm{z}$ 変換值が漸近的にせよ 標準正規分布に従うことは未だに証明されていないので，あくまで もこの值は目安と考えるべきである.

表 5: 八王子市明神町の 1989 年の辺率の $\mathrm{z}$ 変換値

\begin{tabular}{|c|c|c|c|c|c|c|c|}
\hline \multirow[t]{3}{*}{ 区 } & \multicolumn{7}{|c|}{$\mathrm{z}$ 変換值 } \\
\hline & 空地 & 工業 & 低層 & 高層 & 商業 & 道路 & 公共 \\
\hline & & 用地 & 住宅 & 住宅 & 業務 & & 施設 \\
\hline 空 & 35.8 & -5.2 & -7.0 & -2.6 & -5.6 & -2.1 & -5.8 \\
\hline 工 & -4.6 & 35.6 & -6.2 & -3.1 & -7.5 & -7.7 & -8.1 \\
\hline 低 & -4.6 & -4.6 & 30.2 & -5.0 & -12.2 & -11.8 & -10.8 \\
\hline 高 & -2.3 & -3.3 & -7.6 & 24.2 & -5.5 & 5.6 & -7.8 \\
\hline 商 & -4.4 & -6.0 & -14.2 & -4.2 & 29.4 & -2.3 & -10.4 \\
\hline 道 & -2.0 & -6.8 & -15.2 & 4.6 & -2.3 & 25.1 & -5.6 \\
\hline 公 & -5.1 & -8.1 & -15.1 & -7.1 & -12.3 & -6.0 & 48.7 \\
\hline
\end{tabular}

6 おわりに

この論文では, 同边率2)314)を抁張して, 同種・異種の土地利用の 隣接集塊性を分析する指標としての辺率を提案した．また，ランダ ムな土地利用図における辺率の挙動，特に従来は不明であった異辺 率の挙動を解析し，辺率の解釈の方法について論じた。

残された課題としては，辺率の $\mathrm{z}$ 変換値のより厳密な解釈の方法 や，単純なランダムな土地利用図よりも実際の土地利用図に近いモ デル土地利用図での辺率の挙動の解析が挙げられる.

また，吉川4)で指摘された同辺率のメッシュサイズを変えたときの 挙動を含めて，メッシュサイズを変えたときの辺率の挙動もこれか らの課題として残っている注 1).

なお，実際の都市においては，土地利用の間に外部性などの複雑 に相互に影響を及ぼし合う関係が存在する。この論文の手法はこれ らの複雑な関係は一旦捨象して，土地利用区分相互の隣接関係を計 量することを目的とした。したがって，より複雑な相互関係を織り 込んだ指標の開発も将来の課題である.

謝辞

この研究に当たって東京都立大学都市研究費共同研究「大都市地 域の地域情報と空間システムに関する計画論（1994〜97 年度)」「循 環型社会とまちづくりに関する総合的研究（1998２001 年度)」の 援助を受けた．また本稿の医名査読者より下記の注を含めて有益な 助言を得た。ここに記して謝意を表したい.

注

注 1) 匿名查読者の指摘による.

\section{参考文献}

1) 吉川徹：メッシュデータを使った同種・異種の土地利用の集塊性の分析 手法, 日本建築学会大会学術講演梗概集, F-1 分冊, pp.667-668, 1997

2) 吉川徹 : 同一辺数比率に着目したメッシュ土地利用データ分析手法, 日 本建築学会大会学術講演梗概集, F-1 分冊, pp.543-544, 1995

3) 吉川徹：メッシュ当たりの同一辺数による土地利用の集塊性の分析手法, 総合都市研究（東京都立大学都市研究所紀要），第 56 号，pp.61-71，1995

4) 吉川徹 : メッシュデータに立脚した土地利用の集塊性の把握手法につい $\tau$, 日本建築学会計画系論文集, No.495, pp.147-154, 1997

5) 小出治：土地利用混合度の適用並びにその検定，日本都市計画学会学術 研究論文集, 第 12 号, pp.79-84, 1977 
6）玉川英則：土地利用の秩序性の数理的表現に関する考察，日本都市計画 学会学術研究論文集, 第 17 号, pp.73-78, 1982

7) Upton, G. and Fingleton, B. : Spatial Data Analysis by Example, Vol.1, John Wiley. \& Sons, p158, 1985

8）玉川英則：都市内における土地利用の秩序性の計量的表現に関する研

究，東京大学工学系研究科都市工学守門锞程博士論文, “'1986

9) 文泰憲, 萩島哲, 大貝彰：土地利用混合度指標に関する研究，日本都市 計画学会学術研究論文集, 第 26 号, pp.505-510, 1991

10）福島徹：GISデータを用いた土地利用評価指標，GIS-理論と芯用，第

2 卷, pp.75-82, 1994

11）武内和彦，恒川篤史：環境資源と情報システム，古今書院，pp.121-130, 1994

12）奥野隆史：都市と交通の空間分析，pp.5-15，大明堂，1996

13）日本科学技術研究所：望ましい都市規模，形㸃，分布に関する基礎調 查報告書, pp.74-81, 1979

14）恒川篤史，李東根，米林聡，井手久登:土地利用混在の定量化手法，
境情報科学, 第 20 巻第 2 号, pp.115-120, 1991

15）山中知彦，原庆司，藤井昭，渡辺煡一，㭂駒幸江：ダラフ化による土地 利用図の分析, 日本都市計画学会学術研究論文集, 第 16 巻, pp.13-18, 1981 16）吉川徹，坂内正夫，大沢裕，峯村治実：ベクトル化による土地利用図 のデータ化とその定量的分析のための手法に関する一考察, 日本不動産学会 秋季全国大会梗概集，第 2 号, pp.31-34，1986

17）関谷忠夫：八重桖直人，伊藤邦明：都市域における植生の「連続性」 「塊状性」に関する定量化手法, 日本建築学会大会学術講演梗概集, F-1 分 冊, pp.679-680, 1996

18）山崎正晴，伊藤圭，関谷忠夫，野村希晶，伊藤邦明：塊状植生被覆を 用いた都市稙生の評価手法に関寸る研究，日本建築学会大会学術譜演梗概集， F-1 分冊, pp:655-656, 1998

19）建設省国土地理院：数值地図コーザーズガイド（第 2 版補鲀版），(財） 日本地図センター, 1998

20）青木義次，永井明子，大佛俊泰：遷移確率行列を用いた土地利用分析に おける誤差評価，日本建築学会計画系論文集，第 456 号，pp.171-177，1994 